\title{
EFEKTIFITAS NILAI-NILAI PENDIDIKAN KARAKTER DALAM FABEL PADA MATERI PEMBELAJARAN BAHASA INGGRIS
}

\author{
Salmia Syarifuddin*1, Irmawaty Hasyim ${ }^{2}$ \\ $1^{*} .2$ Prodi Pendidikan Bahasa Inggris, Fakultas Sastra, Universitas Muslim Indonesia, Makassar, \\ Indonesia \\ e-mail: *1salmia.syarifuddin@umi.ac.id, ${ }^{2}$ irmawaty.hasyim@umi.ac.id
}

\begin{abstract}
ABSTRAK
Penelitian ini bertujuan untuk mengetahui efektifitas fabel sebagai bahan ajar terutama dalam pembelajaran Bahasa Inggris yang terdapat fabel. Penelitian ini menggunakan metode deskriptif kualitatif. Sumber data penelitian ini adalah fabel. Data dalam penelitian ini dapat berupa frasa, baik itu frasa kata benda ataupun kata kerja, klausa serta kalimat yang ditemukan dalam fabel. Teknik pengumpulan dan analisis data yang digunakan adalah teknik analisis teks. Hasil penelitian menunjukkan bahwa nilai pendidikan karakter yang banyak muncul dalam fabel, diantaranya; nilai religious, kejujuran, kreatif, bersahabat/ komunikatif, kerja keras, ingin tahu, dan toleransi. Selain itu, efektifitas penggunaan fabel sebagai media pembelajaran mahasiswa menunjukkan hasil yang signifikan dan berada pada skala $77 \%$.

Kata Kunci: fabel, karakter, pendidikan karakter, Pendidikan Bahasa Inggris
\end{abstract}

\begin{abstract}
This study aimed to find out the effectiveness of fable as learning materials, particularly in English teaching materials which contains fable. This study applied qualitative descriptive method. The source of data was taken from fable. The data could be in the form of phrase, words or clause, or sentences taken from the fable. The data collection and analysis applied content analysis technique. The research result showed that the values of character education which mostly appeared were religious, honest, creative, friendly/communicative, hard-working, curiosity, tolerance. For the effectiveness of using fable as learning material for university students showed significant result and appeared in the scale of $77 \%$.
\end{abstract}

Keywords: fable, character, character building, English Education

\section{PENDAHULUAN}

Karya sastra banyak dijadikan sebagai salah satu objek yang dipilih sebagai media pembelajaran Bahasa Inggris. Karya ini bisa berupa puisi, syair, cerita pendek atau cerpen, dan lain sebagainya. Pemilihan karya sastra sebagai media pembelajaran memiliki alasan khusus yakni dalam hal konten dari karya tersebut. Karya sastra merupakan tulisan yang mencerminkan tentang kehidupan sosial bermasyarakat dan berbudaya yang secara langsung ataupun tidak langsung dapat memberikan berbagai pengalaman didalamnya. Pengalaman ini kemudian dapat dipetik dan tentu saja memiliki nilai moral atau pendidikan karakter bagi pembacanya.

Salah satu karya sastra yang sarat akan nilai-nilai pendidikan karakter adalah fabel. Fabel merupakan satu bentuk karya sastra yang berupa dongeng. Fabel ini menggunakan karakter yang dalam ceritanya banyak diperankan oleh binatang. Karakter binatang ini banyak meniru atau membawakan sifat manusia dalam perannya. Meskipun fabel merupakan bentuk prosa yang bersifat fiksi, namun dalam alur ceritanya terdapat berbagai segi kehidupan manusia. Alur cerita ini senantiasa memberikan dan menggambarkan pentingnya pendidikan karakter sejak dini kepada manusia. Perlu digaris bawahi bahwa peminat dari fabel ini banyak berasal dari usia dini atau anak remaja. Namun, tidak menutup kemungkinan, banyak juga orang dewasa yang senang dengan kisah-kisah fabel. Hal ini dipicu oleh alur fabel itu sendiri, yang mana selain menampilkan karakter binatang, alurnya juga memberikan kesegaran kepada peminatnya berupa kisah yang lucu dan menarik.

Pendidikan karakter atau dikenal dengan istilah character building menggunakan beberapa istilah yang lazim digunakan oleh peneliti. Pada penelitian-penelitian sebelumnya, terdapat 
beberapa peneliti yang menggunakan istilah nilai moral (moral lesson), ataupun nilai karakter. Dengan demikian, Pendidikan karakter ini merupakan hal yang banyak diperhatikan oleh peneliti terutama dalam membangun dan membentuk karakter anak sejak dini.

Pendidikan karakter merupakan hal penting yang saat ini banyak dirumuskan dalam pembelajaran baik itu pendidikan di tingkat dasar maupun di tingkat pendidikan tinggi. Dalam dunia pendidikan, pendidikan karakter disebut juga sebagai soft skill. Di zaman yang penuh dengan keterbukaan ini, soft skill dibutuhkan sebagai salah satu unsur dalam Menyusun kurikulum Pendidikan. Saat ini dunia pendidikan baik itu di tingkat pendidikan dasar hingga pendidikan tinggi memasukkan kemampuan berupa soft skill ke dalam kurikulumnya, sehingga dengan demikian tenaga pendidik maupun terdidik harus ikut berperan aktif untuk membangun soft skill tersebut dengan meningkatkan kecerdasan emosional yang dimiliki anak didik.

Norma kehidupan dan pendidikan karakter yang dipaparkan Harun Yahya dalam karyanya yang berjudul 'Stories for Thinking Children 1' merupakan buku yang berisi kumpulan fabel. Buku ini dapat memberikan sumbangan penting dalam pembentukan kepribadian masyarakat atau pembacanya. Disamping itu, meskipun fabel ini terkesan diperuntukkan untuk anak-anak, namun fabel juga dapat dijadikan materi bahan ajar di bangku perkuliahan. Alasannya sederhana, selain fable berisi nilai-nilai masyarakat dan pendidikan karakter, fabel berbahasa Inggris juga sarat akan bahasa yang indah, yang mengandung nilai estetika yang tinggi.

Dalam penelitian ini penulis hanya mengkaji beberapa fabel dalam buku Harun Yahya yang diterbitkan pada bulan Desember 2003. Fable karya Harun Yahya dalam buku tersebut berjumlah Sembilan belas (19), diantaranya (1) "Omar and the Penguin", (2) "Maqsud and the Kitten", (3) "Sayid and the Squid", dan (4) "Cute Long-Tailed Squirrels" [1].

\section{Fabel sebagai Salah Satu Karya Sastra}

Sebagai salah satu bentuk karya sastra yang sangat disenangi baik itu anak-anak hingga dewasa, fabel tergolong karya sastra yang menarik. Fabel banyak ditulis untuk menyampaikan pesan moral dan pendidikan karakter kepada para pembacanya. Selain ceritanya yang lucu dan menarik, terkadang fabel menghadirkan alur cerita yang menegangkan.

Fabel atau yang dalam bahasa Indonesia dikenal sebagai dongeng binatang tergolong sebagai karya sastra berupa prosa pendek. Sebagai suatu karya yang tergolong pendek, tentu saja fabel berbeda dengan karya se-genrenya. Ada beberapa hal yang membedakan fabel dengan prosa lainnya. Perbedaan yang dimaksudkan diantaranya; dalam fabel senantiasa disertai dengan sifat cerita jenaka yang ditampilkan karakternya.

Karakter dalam fabel ini diperankan oleh binatang yang mewakili sifat manusia. Inilah letak keunikan fabel. Selain itu, alur ceritanya mulai dari awal, klimaks hingga akhir cerita, fabel berisikan pesan moral (moral lesson) yang juga dikenal sebagai pendidikan karakter dari alur cerita fabel. Disamping itu, satu hal yang juga merupakan pesan tersirat dan alur ceritanya yang selalu diakhiri secara damai, akhir bahagia (happy ending). Sebagai jenis karya sastra yang mengedepankan pesan moral atau pendidikan karakter, fabel tentu saja tidak mengandung unsurunsur khayalan ataupun sihir seperti yang terdapat dalam mitos atau mite (myth) dan legenda (legend).

Dalam bahasa Inggris, dongeng disebut cerita peri (fairy tales), cerita kanak-kanak (nursery tales), atau cerita ajaib (wonder tales). Adapun ciri dongeng, biasanya mempunyai kalimat pembuka dan kalimat penutup yang bersifat seragam dan sama terus menerus, seperti one upon a time, there lived a..... (pada suatu waktu hidup seorang..........) atau pada bahasa Melayu diawali kalimat pembuka seperti, "sahibul hikayat......"[2]. Didalam buku the Types of the Folktale (1964, h.19-20), Anti Aarne dan Stith Thompson telah membagi jenis dongeng kedalam empat golongan besar, yaitu: dongeng binatang, dongeng biasa, lelucon atau anekdot, dongeng berumus. Dongeng binatang (fable) adalah dongeng yang ditokohi binatang peliharaan dan binatang liar, seperti binatang menyusui, burung, binatang melata (reptillia), ikan, dan serangga. Binatang-binatang itu dalam cerita jenis ini dapat berbicara dan berakal budi seperti manusia.

Budaya rakyat merupakan ekspresi religiusitas rakyat. Untuk menggali hal tersebut perlu dilacak folklife, artinya folklor yang hidup di masyarakat. Folklor yang masih berkembang, 
mungkin sekali menggambarkan emosi dan budaya rakyat [3]. Hal ini perlu dilakukan, karena terkadang dalam folklore tanah air itu mengandung unsur fabel. Unsur tersebut terletak pada karakter dalam folklore yang biasanya menggunakan satu atau dua karakter binatang dalam alur ceritanya.

Keuntungan dari menggunakan folklor termasuk didalamnya perkembangan holistic, kognitif, moral, Bahasa dan hubungan sosial. Folklor dapat menjadi bahan bacaan alternatif bagi anak, tentu saja sepanjang orang tua dapat memilihkan bacaan yang didalamnya terdapat wawasan yang dibutuhkan pembaca. Selain itu, perlu digaris bawahi bahwa hal ini bersentuhan dengan umur dan minat baca pembaca, tentu saja juga tergantung pada konten dan kompleksitas dari cerita atau folklore yang dibaca [4].

Anak-anak merupakan pendengar yang ahli dengan pengalaman membaca sebelumnya sebagai peserta dalam proses pementasan story telling. Folklor dan dongeng menarik perhatian anak-anak; cerita yang lebih Panjang kemudian dinikmati; dan buku dengan karakter tokoh yang atau plot yang kompleks lebih dipahami. Banyak pendengar berpengalaman yang menjadi pendamping storyteller atau mereka sendiri yang menjadi pendongeng [5]. Pendapat ini sejalan dengan pengimpelentasian cerita dongeng atau fabel dalam pembentukan karakter anak sejak dini.

Dongeng diturunkan secara turun temurun dari satu generasi ke generasi selanjutnya, memperkaya generasi muda dengan nilai-nilai, kepercayaan, imajinasi dan kreativitas. Karya sastra untuk anak-anak masih memainkan peran pentung dalam Pendidikan karena sastra ini mengandung pengetahuan dan hiburan, serta merepresentasikan contoh tertentu dari "edutainment" [6].

Proses pembelajaran di sekolah belum bisa membentuk lulusan yang secara keseluruhan mencerminkan karakter bangsa. Proses Pendidikan masih menekankan dan memfokuskan pada luarannya pada aspek kognitif. Disisi lain, aspek afektif yang menjadi pondasi kuat bagi siswa untuk bergaul dalam masyarakat belum dikembangkan seoptimal mungkin. Oleh karena itu, Pendidikan karakter harus dikembangkan di sekolah. Salah satu cara terbaik adalah dengan memperkenalkan folklore dalam kelas English for Foreign Language (EFL) [7]. Folklor berisi nilai-nilai nasihat yang bijak yang dapat dijadikan sebagai materi pembelajaran, sehingga folklore ini kemudian memiliki relevansi dengan perkembangan karakter siswa [8].

Fable bukan hanya cerita lucu, namun juga mengandung nilai-nilai moral didalamnya. Setiap fabel memiliki, sekurang-kurangnya satu nilai moral dalam narasinya, seperti; Jangan memandang remeh lawan yang lemah, Tidak mudah menyerah adalah kunci kesuksesan, Pikirkan sebelum berbuat [9]. Dengan demikian, nilai-nilai inilah yang dimaksudkan nilai Pendidikan karakter pada fabel.

Atmaja [10] menjelaskan bahwa sebuah karya sastra tidak terlepas dari nilai-nilai yang terkandung didalamnya, yaitu.

1. Nilai Moral, sebuah karya sastra secara umum membawa pesan dan amanat, pesan moral dapat disampaikan langsung atau tidak langsung oleh seorang pengarang, dan pesan moral dapat diketahui dari perilaku tokoh-tokohnya.

2. Nilai Estetis, nilai estetis merupakan nilai keindahan yang melekat pada dongeng tersebut, seperti rima, diksi, atau gaya.

3. Nilai Budaya, nilai budaya dan sosial tidak terlepas dari karya sastra tersebut bercerita tentang daerah tertentu. Aspek budaya tersebut dapat diketahui dari latar atau setting, tokoh, corak masyarakat, kesenian ataupun kebudayaan.

Dari ketiga nilai yang terkandung dalam karya sastra seperti yang diutarakan oleh Atmaja diatas, maka dalam penelitian ini penulis akan fokus pada nilai moral atau yang biasa disebut sebagai nilai pendidikan karakter.

\section{Nilai Pendidikan Karakter dalam Karya Sastra}

Pendidikan karakter memiliki esensi dan makna yang sama dengan pendidikan moral dan pendidikan akhlak. Tujuan dari keberadaan Pendidikan karakter ini adalah untuk membentuk pribadi anak, supaya menjadi manusia yang baik, warga masyarakat yang baik, dan warga negara yang baik bagi suatu masyarakat atau bangsa, secara umum adalah nilai-nilai sosial tertentu yang 
banyak dipengaruhi oleh budaya masyarakat dan bangsanya. Oleh karena itu, hakikat dari pendidikan karakter dalam konteks pendidikan di Indonesia adalah pendidikan nilai, yakni pendidikan nilai-nilai luhur yang bersumber dari budaya bangsa Indonesia itu sendiri, dalam rangka membina kepribadian generasi muda [11].

Pendidikan karakter merupakan salah satu upaya dalam menghadapi degradasi moral yang mengancam nilai karakter bangsa Indonesia. Salah satu cara untuk mengatasi ancaman ini yakni dengan menggunakan metode cerita sebagai media pembelajaran, yang dapat digunakan oleh semua kalangan, baik itu anak-anak, maupun orang dewasa [12]. Untuk menghadirkan cerita ditengah-tengah peserta didik ataupun mahasiswa, hal yang perlu diperhatikan adalah minat atau ketertarikan dari peserta didik terhadap cerita yang dipilih untuk dijadikan bahan atau media pembelajaran.

Gufron menjelaskan bahwa karakter adalah tabiat, kepribadian, identitas atau jati diri yang melekat pada diri seseorang yang berkaitan dengan dimensia psikis dan fisik. Pada tataran mikro, karakter adalah (1) kualitas dan kuantitas reaksi terhadap diri sendiri, orang lain, dan situasi tertentu; serta (2) watak, akhlak, dan ciri psikologis [13]. Dengan demikian, dapat dikatakan bahwa karakter merupakan kepribadian yang dimiliki seseorang yang melekat dan memengaruhi sisi psikis dan fisik seseorang yang kemudian tergambar dan terealisasi dalam setiap tindakan, baik itu secara sadar maupun tidak sadar.

Keragaman pendidikan karakter telah diteliti peneliti sebelumnya, diantaranya Yono pada tahun 2014 yang menemukan bahwa dalam fabel Sentani, karya sastra klasik masyarakat Papua terdapat beberapa karakter universal yang dapat diambil, diantaranya; cinta terhadap Tuhan dan cinta terhadap makhluk ciptaan-Nya, kerja keras, kejujuran, dan rendah hati [14]. Nilai-nilai inilah yang nantinya dapat dijadikan pijakan bagi generasi muda yang menyimak fabel Sentani tersebut dan dampaknya akan sangat besar pada pembentukan karakter anak pada masyarakat setempat.

Prasetyo menggambarkan bahwa fabel merupakan salah satu cerita yang digemari anak di seluruh dunia, sehingga dapat menjadi media yang menarik dalam rangka pembinaan karakter pada dunia pendidikan. Nilai-nilai moral yang disampaikan dengan mengangkat tokoh-tokoh hewan dapat menjadi tema yang menarik dalam ungkapan ilustrasi dengan berbagai pendekatan. Salah satu pendekatan yang biasanya digunakan adalah pendekatan personifikatif. Pendekatan personifikatif merupakan salah satu pendekatan pada gambar ilustrasi yang menarik khususnya bagi anak [15]. Dalam pendekatan personifikatif hewan-hewan yang digambarkan yaitu hewan yang bertingkah seperti manusia. Contohnya adalah gajah yang berjalan dengan dua kaki, harimau yang memakai baju, dan lain sebagainya yang digambarkan dengan lebih sederhana sehingga lebih menarik perhatian anak. Tentu dalam bahasa yang mudah dicerna dan dimengerti oleh anak. Hal inilah yang menyebabkan fabel menarik untuk dijadikan media pembelajaran terutama pada mahasiswa pendidikan Bahasa Inggris, yang nantinya akan berperan mengajar siswa. Dengan demikian, selain mengajar, calon guru ini kelak akan mendidik dengan secara tidak langsung disetiap materi yang disampaikannya.

Jika kita mengharapkan siswa agar bisa bertanggung jawab pada masyarakat, bertingkah laku dengan cara yang beretika dan bertanggung jawab, maka memiliki kompetensi seperti keahlian refleksi etika atau Pendidikan karakter harus dikembangkan di sekolah [16]. Nilai ini tentu saja akan berkembang pada siswa apabila di setiap pembelajarannya, tersedia media pembelajaran atau bahkan dibuatkan media pembelajaran yang didalamnya terdapat unsur cerita yang tentu saja sarat akan nilai-nilai Pendidikan karakter.

Aplikasi game edukasi Icando dapat berkontribusi dalam penguatan nilai-nilai pendidikan karakter diantaranya nilai karakter percaya diri, hormat dan santun kepada orang tua, tanggung jawab, rasa ingin tahu, menghargi prestasi, peduli sosial, peduli lingkungan, kreatif, dan pantang menyerah [17]. Dengan demikian, tidak semua game memberikan dampak negatif pada anak, namun juga positif. Hal ini dapat dilihat pada perkembangan game di zaman digital saat ini yang mana game atau permainan secara online telah sangat berkembang dengan pesat. Bahkan, ada beberapa diantaranya yang menampilkan cerita-cerita yang bias akita temui dalam buku diktat siswa sebagai karakter dalam permainannya.

KENDALA MAHASISWA DALAM ANALISIS MAKNA SEMANTIK PADA BAHAN AJAR BERBAHASA INGGRIS

(SALMIA SYARIFUDDIN*1, IRMAWATY HASYIM²) 
Pendidikan karakter diawali dengan pendidikan budi pekerti pada anak yang dapat disampaikan melalui bermacam-macam media, salah satunya melalui tembang jawa pengantar tidur. Nilai-nilai karakter yang terdapat dalam tembang "Lelo Ledhung", yaitu religiusitas, kesabaran, kasih sayang, dan kebijaksanaan [18].

Bahan ajar teks cerpen yang berorientasi pendidikan karakter mempersyaratkan adanya materi dan contoh serta kegiatan pembelajaran yang dapat memberikan informasi dan dapat ditanamkan pada siswa untuk penguatan karakter yang diharapkan dalam kurikulum. Internalisasi nilai karakter adalah upaya penanaman nilai-nilai karakter kepada para siswa yang meliputi nilai agama, nilai budaya, nilai moral, dan nilai sosial. Bahan ajar teks cerpen untuk siswa SMA ini dirancang dengan karakteristik ulasan materi, pemilihan materi, kegiatan pembelajaran, dan latihan-latihan yang ada dalam buku semuanya berorientasi pada pendidikan karakter misalnya karakter keingintahuan untuk memperoleh pngetahuan, jujur, bekerja sama, dan tanggung jawab [19]. Dengan demikian, keberadaan media pembelajaran berupa cerita-cerita rakyat (folklore) atau fabel dalam bahan ajar tentu saja sangat membantu dalam Pendidikan karakter peserta didik.

Cerita anak sebagai bahan ajar diurutkan sebagai berikut: (a) petunjuk proses pembelajaran, (b) pencapaian kompetensi, (c) isi bahan ajar, (d) informasi tentang nilai-nilai, dan (e) pertanyaan untuk mengembangkan aspek kognitif, psikomotor, and afektif siswa. Model berisi: (a) pengintegrasian nilai-nilai di dalam RPP, (b) pengkondisian pembelajaran nilai-nilai, (c) penginternalisasian nilai-nilai, dan (d) pengembangan nilai-nilai yang ditanamkan melalui pembiasaan di mata pelajaran yang relevan [20].

Berdasarkan keberagaman nilai budaya yang berorientasi karakter, secara umum pada tahun 2010 Kemendiknas merumuskan delapan belas nilai pendidikan karakter yang harus dikembangkan pada diri anak, Kedelapan belas nilai pendidikan karakter ini tentu saja dapat pula dikembangkan melalui proses membaca pemahaman termasuk juga dalam membaca fabel [21]. Adapun nilai dan deskripsi nilai pendidikan budaya dan karakter bangsa yang dirumuskan oleh Kemendiknas, sebagai berikut.

1. Nilai religi

2. Nilai Kejujuran

3. Nilai Toleransi

4. Nilai Disiplin

5. Nilai Kerja Keras

6. Nilai Kreatif

7. Nilai Mandiri

8. Nilai demokratis

9. Nilai rasa ingin tahu

10. Nilai semangat kebangsaan

11. Nilai cinta tanah air

12. Nilai menghargai prestasi

13. Nilai bersahabat/ komunikatif

14. Nilai cinta damai

15. Nilai gemar membaca

16. Nilai peduli lingkungan

17. Nilai peduli sosial

18. Nilai tanggung jawab

Dengan demikian, berdasarkan uraian di atas, nilai-nilai pendidikan karakter yang dipilih penulis untuk dikaji dalam penelitian ini adalah delapan belas nilai sesuai rumusan Kemendiknas. Penulis memilih kedelapan belas nilai pendidikan karakter itu sebagai kajian dalam penelitian ini karena nilai-nilai tersebut sesuai dengan visi misi Universitas Muslim Indonesia (UMI) dalam menghasilkan luaran yang berakhlakul kharimah, berilmu amaliah dan beramal ilmiah. 


\section{METODOLOGI PENELITIAN}

Penelitian ini menggunakan metode deskriptif kualitatif. Metode deskriptif kualitatif merupakan metode yang membuat deskripsi atau gambaran untuk memahami fenomena tentang apa yang dialami oleh subjek penelitian misalnya perilaku, persepsi, motivasi, tindakan, dan lainlain [22]. Data yang diperoleh (berupa kata-kata, gambar, perilaku) tidak dituangkan dalam bentuk bilangan atau angka statistik, melainkan tetap dalam bentuk kualitatif yang memiliki arti lebih dari sekadar angka atau frekuensi. Pengumpulan data dalam penelitian ini dilakukan dengan cara mengumpulkan data berupa phrase, kalimat dan penggalan wacana (klausa) yang mengandung nilai-nilai pendidikan karakter dalam fabel karya Harun Yahya yang bersumber dari bukunya yang berjudul 'Stories for Thinking Children 1'. Teknik analisis data yang dilakukan penulis yakni dengan menggunakan teknik analisis teks. Teknik ini digunakan untuk mendeskripsikan karakter-karakter yang ditemukan dalam fabel karya Harun Yahya.

\section{HASIL DAN PEMBAHASAN}

\section{Hasil Penelitian}

Berdasar pada perolehan data hasil penelitian, pembahasan hasil penelitian di bawah difokuskan pada deskripsi nilai pendidikan karakter pada fabel karya Harun Yahya yang diteliti dan yang terkait dengan efektifitas pemilihan fabel tersebut sebagai bahan ajar pembelajaran bahasa Inggris pada mahasiswa semester dua (2) program studi pendidikan Bahasa Inggris, Fakultas Sastra, Universitas Muslim Indonesia (UMI) Makassar.

Adapun Fabel Harun Yahya yang digunakan sebagai media pembelajaran dalam penelitian ini, yakni sebanyak empat (4) judul fabel, diantaranya; (1) Long-Legged Storks, (2) Omar and the Penguin, (3) Jamal and the Parrot dan (4) Naeem and the Pretty Peacock.

Nilai-Nilai Pendidikan Karakter dalam Fabel Karya Harun Yahya dapat ditunjukkan sebagai berikut. Aspek nilai pendidikan karakter yang dijadikan acuan adalah nilai-nilai pendidikan karakter sebagaimana yang disarankan Kemendiknas (2010) untuk dijadikan panduan pembelajaran pendidikan karakter dan budaya bangsa. Pendidikan karakter seperti yang dianalisis dalam penelitian ini merupakan salah satu cara dalam mendidik dengan menggunakan media fabel sebagai salah satu karya sastra yang ditulis oleh penulis besar seperti Harun Yahya. Dalam penelitian ini, nilai-nilai itu tidak dibelajarkan secara terpisah dan tersendiri, melainkan diharapkan dapat dibelajarkan secara terpadu dalam fabel yang digunakan sebagai media pembelajaran dalam penelitian ini.

Tabel 1. Nilai Pendidikan Karakter dalam Fabel Karya Harun Yahya

\begin{tabular}{llccc}
\hline No. & Fabel & Jumlah Nilai & \multicolumn{2}{c}{ Jumlah Mahasiswa (48) } \\
\cline { 4 - 5 } & & Karakter & Frekuensi & Persen \\
\hline $\mathbf{1}$ & Long-Legged Storks & 4 & 16 & 33,3 \\
\hline $\mathbf{2}$ & Omar and the Penguin & 7 & 37 & 77,08 \\
\hline $\mathbf{3}$ & Jamal and the Parrot & 6 & 23 & 47,09 \\
\hline $\mathbf{4}$ & Naeem and the Pretty and Peacock & 7 & 39 & 81,25 \\
\hline
\end{tabular}

Berdasarkan pada Tabel 1. dapat dilihat dalam fabel 'Long-Legged Storks' ditemukan empat (4) nilai pendidikan karakter, yakni; nilai toleransi, nilai kerja keras, nilai disiplin dan nilai cinta tanah air. Pada fabel kedua yang berjudul 'Omar and the Penguin', ditemukan tujuh (7) jenis nilai pendidikan karakter. Ketujuh nilai ini, antara lain; nilai rasa ingin tahu, nilai bersahabat/ komunikatif, nilai religious, nilai kreatif, nilai peduli sosial, nilai peduli lingkungan dan nilai kejujuran. Sementara pada fabel 'Jamal and the Parrot' ditemukan enam (6) nilai pendidikan karakter, yakni; nilai rasa ingin tahu, nilai bersahabat/ komunikatif, nilai kerja keras, nilai kreatif, nilai religious dan nilai toleransi. Dan pada fabel yang terakhir, yang berjudul 'Naeem and the Pretty Peacock', juga ditemukan tujuh (7) nilai pendidikan karakter, yaitu; nilai bersahabat/ komunikatif, nilai kejujuran, nilai rasa ingin tahu, nilai mandiri, nilai religious, nilai menghargai 
prestasi dan nilai tanggung jawab. Dengan demikian, pada keempat fabel yang dijadikan media pembelajaran dalam penelitian ini, ditemukan bahwa nilai pendidikan karakter yang paling sering muncul yakni nilai bersahabat/ komunikatif dan nilai rasa ingin tahu.

Pada nilai bersahabat/ komunikatif, tentu ada nilai yang berkaitan bagaimana menjalin silaturrahim dengan sesama. Hal ini juga dikenal dengan nilai bersahabat atau komunikatif. Dalam fabel karya Harun Yahya yang dibahas dalam peneltian ini, juga mengandung nilai bersahabat/ komunikatif.

"It's really freezing here. Don't you ever get cold?"

("Disini dingin sekali. Tidakkah kau merasa kedinginan?")

(Kutipan dari fabel Omar and the Penguin karya Harun Yahya)

Kutipan diatas menunjukkan adanya sikap yang ingin menjalin komunikasi dari Omar kepada lawan bicaranya yakni si Penguin. Dengan kata lain, Omar berusaha membangun komunikasi dengan si Penguin. Berdasar pada niat Omar inilah maka kutipan ini menunjukkan adanya nilai bersahabat/ komunikatif. Selain Omar ingin membangun komunikasi, rasa ingin tahu juga merupakan salah satu faktor Omar bertanya, meskipun Omar belum begitu akrab dengan lawan bicara.

\section{"I want to feed you really well."}

"I also will do everything I can to make sure you are comfortable here."

("Saya ingin merawat/ memberi makan kamu dengan baik.Saya juga akan melakukan apapun agar kamu nyaman tinggal disini.")

Kutipan dari fabel Jamal and the Parrot diatas menunjukkan niat dari Jamal untuk lebih mendekatkan dirinya kepada kawan barunya. Sebagai kawan baru yang akan tinggal dengannya, tentunya ia ingin membuat temannya nyaman tinggal di rumahnya. Oleh karena itu, Jamal berusaha sebaik mungkin demi kenyamanan teman barunya. Hal inilah yang menunjukkan adanya pesan moral dari fabel ini berupa pendidikan karakter dengan nilai bersahabat/ komunikatif.

"I am known as the most splendid looking creature in the animal kingdom."

("Saya dikenal sebagai hewan yang paling mewah/ cantik di dunia binatang.")

Kutipan diatas merupakan salah satu kalimat dalam fabel Naeem and the Peacock. Dari kutipan diatas, Nampak sang Burung Merak sedang memperkenalkan dirinya kepada Naeem, seorang anak yang berkunjung ke kebun binatang. Si Merak berkata demikian dikarenakan kekaguman Naeem akan bulu ekor si Merak yang begitu indah ketika dilebarkan. Untuk menjalin komunikasi dengan Naeem, si Merak pun memperkenalkan dirinya sebagai binatang yang paling cantik di jagad raya ini. Hal ini tentu saja benar adanya, karena ketika si Merak melebarkan sayapnya, taka da satu binatang pun yang dapat menyaingi kecantikannya. Dengan terkagum-kagum dan keramahan yang ditunjukkan oleh si Merak, maka Naeem pun kemudian lama berbincang dengan si Merak, meskipun mereka belum pernah ketemu sebelumnya. Hal inilah yang menunjukkan nilai bersahabat/ komunikatif dalam fabel Naeem and the Pretty Peacock.

Kasus yang sama juga muncul pada nilai karakter untuk nilai rasa ingin tahu. Rasa keingintahuan dimiliki seseorang bila mendapatkan atau menemui sesuatu yang baru. Hal ini banyak dihadapi oleh pembaca atau penikmat karya sastra seperti fabel, baik itu dewasa maupun anak-anak.

Berikut kutipan dari fabel Omar and the Penguin:

He thought about what he had seen.

(Dia memikirkan apa yang dia lihat.)

Dari kutipan kalimat pada fabel Omar and the Penguin diatas, Nampak jelas bahwa Omar menunjukkan rasa ingin tahu. Berdasar pada kalimat tersebut, Omar yang baru saja menonton film dokumenter di TV, memikirkan apa yang baru saja ia lihat ketika hendak tidur. Hal ini menunjukkan rasa ingin tahu, bahkan ingin tahu lebih jauh terkait event yang ada dalam film dokumenter yang baru saja ditontonnya. 
Dalam fabel Jamal and the Parrot, dengan sangat jelas, Jamal menunjukkan rasa ingin tahunya. Berikut merupakan kutipan ucapan Jamal yang menunjukkan rasa ingin tahunya:

"I need to learn everything about you."

("Saya harus tahu segalanya tentangmu.")

Dari kutipan diatas, terlihat jelas sikap Jamal yang sangat optimis akan rasa ingin tahunya tentang Burung Kakatua yang baru saja menjadi hewan peliharaannya. Jamal ingin tahu segalanya tentang si Kakatua, agar ia dapat memeliharanya dengan baik. Disamping itu, merujuk pada kutipan tersebut maka nilai pendidikan karakter terkait nilai rasa ingin tahu merupakan nilai yang paling banyak ditampilkan dalam fabel Jamal and the Parrot ini.

Alasan mengapa nilai-nilai tersebut yang dianggap paling sering muncul, dikarenakan, pengertian dari fabel dan tujuan penulisan fabel itu sendiri. Selain itu, fabel adalah salah satu genre sastra yang merupakan karya dimana karakter atau tokoh ceritanya adalah binatang yang membawakan sifat manusia. Disamping itu, tujuan penulisan fabel adalah memberikan pesan moral pada pembacanya. Meskipun fabel, ditujukan untuk pembentukan karakter pada anak, bila fabel yang diberikan merupakan fabel yang berbahasa Inggris, maka terkadang pembaca akan mengalami kesulitan dalam mendapatkan pesan moral dari fabel tersebut. Dengan demikian, fabel yang digunakan sebagai media pembelajaran dalam penelitian ini dianggap tepat. Hal ini dikarenakan dari sekian banyak genre dan karya sastra, fabel merupakan karya sastra yang disetiap ceritanya senantiasa menampilkan pesan moral. Selain itu, fabel ini juga dikenal sebagai karya sastra yang dibaca dan digemari pembaca dari segala umur, baik itu muda maupun tua.

\section{Pembahasan}

Efektifitas Penggunaan Fabel dalam Pembelajaran Bahasa Inggris dapat diuraikan sebagai berikut. Kuisioner dan wawancara sengaja dilakukan dengan mendistribusikan keingintahuan peneliti terhadap efektifitas nilai-nilai karakter dalam fabel guna meningkatkan minat baca mahasiswa yang mencakup (i) keaktifan mahasiswa belajar ketika fabel dijadikan media pembelajaran; (ii) efektifitas fabel sebagai media pembelajaran; (iii) nilai pendidikan karakter dalam fabel dapat membantu mahasiswa membangun karakter dan; (iv) hal-hal baru yang mahasiswa dapatkan dari fabel sebagai media pembelajaran dan bahan ajar.

Pendapat mahasiswa tentang fabel dan pendidikan karakter dijaring lewat pemberian angket dan wawancara. Setelah diolah dengan statistik deskriptif, hasil angket yang dimaksud ditunjukkan pada Tabel 2.

Tabel 2. Kuisioner Penggunaan Fabel sebagai Media Pembelajaran dalam Mata Kuliah Bahasa Inggris (Reading 2)

\begin{tabular}{cccccc}
\hline \multicolumn{7}{c}{ Jumlah Responden (Mahasiswa) } \\
\hline SS (5) & \multicolumn{1}{c}{ S (4) } & SM (3) & TS (2) & STS (1) \\
\hline $\mathbf{7}$ & 28 & 12 & - & 1 \\
\hline 35 & 112 & 36 & 0 & 1 \\
\hline \multicolumn{7}{c}{ Total Skor } & & 184 \\
\hline
\end{tabular}

Jumlah responden pada penelitian ini sebanyak 48 responden (mahasiswa) Jumlah skor tertinggi (Y) untuk item sangat setuju ialah 5 x $48=240$, sedangkan item terendah $(X)$ sangat tidak setuju ialah 1 x $48=48$. Jadi, jika total skor responden di peroleh angka 184, maka penilaian interpretasi responden terhadap keefektifan fabel untuk dijadikan media pembelajaran dapat diketahui dengan hasil nilai yang dihasilkan dengan menggunakan rumus Index \% berikut.

Rumus Index \% = Total Skor $/ \mathrm{Y}$ x 100

Maka efektifitas fabel:

$=$ Total Skor $/$ Y x 100

$=184 / 240 \times 100$

$=76,66 \%=77 \%$ Kategori SETUJU 
Dengan demikian, penggunaan fabel, dalam hal ini fabel karya Harun Yahya sebagai media pembelajaran pada mata kuliah bahasa Inggris terkhusus mata kuliah Reading 2, mahasiswa semester dua (2) program studi Pendidikan Bahasa Inggris, Fakultas Sastra, Universitas Muslim Indonesia (UMI) dikategorikan efektif.

Hal ini dapat dinyatakan setelah melihat jumlah terbanyak responden angket berada pada kategori setuju, yakni sebanyak 28 orang. Selain itu, hasil interpretasi keefektifan penggunaan fabel sebagai media pembelajaran dalam mengajarkan mata kuliah Reading 2 juga menggunakan nilai index interpretasi yang berada pada kategori setuju. Berdasar pada analisis likert scale, hasil analisis menunjukkan index efektifitas penggunaan fabel sebagai media pembelajaran pada mahasiswa program studi pendidikan Bahasa Inggris, Fakultas Sastra, Universitas Muslim Indonesia (UMI) Makassar berada pada level $77 \%$. Level pada skala index ini berada pada kategori Setuju. Dengan kata lain, 77\% dari mahasiswa semester dua (2) program studi Pendidikan Bahasa Inggris, Fakultas Sastra Universitas Muslim Indonesia setuju ataupun senang bila menggunakan karya sastra berupa fabel sebagai media pembelajaran.

Hasil wawancara menunjukkan pendidikan karakter merupakan suatu pengembangan keilmuwan yang berupaya mengembangkan potensi manusia sebagai makhluk yang dalam berperilaku selalu berpedoman dari nilai-nilai budaya bangsa Indonesia yang religious. Ibaratnya, meski seseorang dianggap cakap dalam keilmuannya, namun tanpa karakter yang kuat ibaratnya bangunan tanpa rangka baja yang kokoh sehingga mudah goyah bahkan dikhawatirkan ilmunya itu malah bisa membuatnya tinggi hati karena merasa lebih dari manusia lainnya. Dari hasil temuan pencarian nilai karakter tersebut, penelitian ini menemukan sejumlah kata, kalimat, maupun frasa yang mengandung nilai karakter tersebut.

Adanya efektifitas dari penggunaan fabel karya Harun Yahya sebagai media dalam penyajian bahan ajar dapat dilihat dalam beberapa hal. Dengan menggunakan fabel, mahasiswa terdorong aktif belajar jika dosen menggunakan fabel sebagai media pembelajaran dan bahan ajar mata kuliah reading di kelas: hampir semua mahasiswa menyatakan sangat setuju, bahkan sebagian besar diantaranya menyatakan sangat setuju bila kelas mata kuliah Reading semester dua, dosen menggunakan fabel sebagai media pembelajaran. Dalam hal pencarian dan pengidentifikasian kata, frasa, kalimat dalam fabel, mahasiswa menyatakan setuju atau senang. Beberapa mahasiswa menambahkan bila belajar mata kuliah reading dengan menggunakan fabel sebagai media pembelajaran, terasa sangat mudah. Nilai pendidikan karakter dalam fabel membantu memahami nilai moral karya sastra. Sebagian besar mahasiswa juga memberikan pernyataan setuju serta menyatakan banyak hal baru yang didapat dalam pembelajaran dengan menggunakan media fabel dalam mata kuliah reading. Selain itu, efektif tidaknya penggunaan fabel sebagai media dalam pembelajaran mata kuliah berbahasa Inggris, seperti pada mata kuliah Reading 2 pada Prodi Pendidikan Bahasa Inggris, Fakultas Sastra UMI dirasakan efektif karena dengan adanya respon positif dan keaktifan mahasiswa selama proses penelitian.

\section{SIMPULAN}

Kesimpulan yang dapat diambil berdasarkan temuan dan pembahasan sebelumnya adalah nilai-nilai pendidikan karakter di dalam fabel karya Harun Yahya adalah nilai religious, kejujuran, kreatif, bersahabat/ komunikatif, kerja keras, ingin tahu, toleransi dan kerja keras. Disamping itu, fabel karya Harun Yahya ini dikategorikan efektif untuk dijadikan media pembelajaran karena mampu menarik minat dan membuat mahasiswa lebih tertarik dalam menghadapi mata kuliah bahasa Inggris, seperti mata kuliah Reading pada Program Studi Pendidikan Bahasa Inggris, Universitas Muslim Indonesia (UMI) Makassar.

\section{REFERENCES}

[1] H. Yahya, "Stories for Thinking Children 1," Istambul Khatoons Inc, 2003.

[2] J. Danandjaja, "Folklor Indonesia - Google Books," Depdikbud, 2002. https://www.google.co.id/books/edition/Folklor_Indonesia/GpRAngAACAAJ?hl=id 
(accessed Aug. 20, 2021).

[3] S. Endraswara, "Folklor nusantara: hakikat, bentuk dan fungsi," Folk. Nusant. hakikat, bentuk dan fungsi, pp. 1-298, 2013, [Online]. Available: http://staff.uny.ac.id/sites/default/files/penelitian/dr-suwardi-mhum/folklornusantaradamicetak.pdf.

[4] S. (Siti) Anafiah, "Pemanfaatan Cerita Rakyat Sebagai Alternatif Bacaan Bagi Anak," Trihayu J. Pendidik. Ke-SD-an, vol. 1, no. 2, pp. 128-133, 2015.

[5] P. D. Zeece, "Bringing Books to Life: Literature-Based Storytelling," Early Child. Educ. J., vol. 1, no. 25, pp. 39-43, 1997, doi: 10.1023/A:1025633914983.

[6] M. Pulimeno, P. Piscitelli, and S. Colazzo, "Children's literature to promote students' global development and wellbeing," Heal. Promot. Perspect., vol. 10, no. 1, p. 13, 2020, doi: 10.15171/HPP.2020.05.

[7] M. Sekewael, F. Pentury, and W. Noija, "Designing Lesson Activities Through Maluku Folklore For Character Education," Int. Conf. Educ. Lang., vol. 0, no. 0, p. 46, May 2016, Accessed: Aug. 21, 2021. [Online]. Available: http://artikel.ubl.ac.id/index.php/icel/article/view/499.

[8] I. W. Agustina, I. M. Sutama, and I. W. Rasna, "Analysis of Character Educational Values in Folklore and the Relevance in the Formation of Student's Character in Vocational High School," J. Penelit. dan Pengemb. Sains dan Hum., vol. 3, no. 1, pp. 36-40, Apr. 2019, doi: 10.23887/JPPSH.V3I1.17362.

[9] M. Abrar, "Learning from Fables: Moral Values Learning from Fables: Moral Values in Three Selected English Stories," Din. Ilmu, vol. 16, no. 1, p. 47, 2016.

[10] J. F. . Atmajaya, Buku Lengkap Bahasa Indonesia dan Peribahasa: SD, SMP, SMA. Pustaka Widyatama, 2010.

[11] H. Gunawan, Pendidikan karakter : konsep dan implementasi. Alfabeta, 2012.

[12] Y. Babuta, Y. Y. I. Babuta, and O. D. Wahyurini, "Perancangan Buku Pendidikan Karakter Toleransi dan Cinta Damai untuk Anak Usia 3-5 Tahun," J. Sains dan Seni ITS, vol. 3, no. 1, pp. F28-F32, Mar. 2014, doi: 10.12962/j23373520.v3i1.6060.

[13] A. Ghufron and A. Ghufron, "Integrasi Nilai-Nilai Karakter Bangsa pada Kegiatan Pembelajaran," J. Cakrawala Pendidik., vol. 1, no. 3, May 2010, doi: 10.21831/cp.v1i3.230.

[14] S. Yono, "Nilai Edukasi dalam Fabel Sentani (The Didactic Value in Sentani Fable) Sri," Kandai, vol. 10, no. 1, pp. 102-115, 2014.

[15] Y. A. Prasetyo, "Ilustrasi Buku Cerita Fabel Sebagai Media Pendidikan Karakter Anak," Arty J. Seni Rupa, vol. 3, no. 1, 2014, doi: 10.15294/ARTY.V3I1.4024.

[16] L. Paakkari and O. Paakkari, "Health literacy as a learning outcome in schools," Health Educ., vol. 112, no. 2, pp. 133-152, Feb. 2012, doi: 10.1108/09654281211203411.

[17] S. Bahri and A. Wahdian, "Penguatan Nilai-Nilai Pendidikan Karakter Melalui Game Edukasi Icando di Sekolah Dasar," J. Pendidik. Dasar Nusant., vol. 6, no. 2, pp. 23-41, Jan. 2021, doi: 10.29407/JPDN.V6I2.15078.

[18] D. P. Arum, "Lelo Ledhung: Representasi Nilai-Nilai Pendidikan Karakter dalam Tembang Jawa Pengantar Tidur untuk Anak," PROCEEDING UMSURABAYA, vol. 0, no. 0, May 2020, Accessed: Aug. 20, 2021. [Online]. Available: http://journal.umsurabaya.ac.id/index.php/Pro/article/view/4822.

[19] D. E. Mascita, "Internalisasi Nilai Karakter Melalui Bahan Ajar Teks Cerpen Beorientasi Pendidikan Karakter," Ling. Rima J. Pendidik. Bhs. dan Sastra Indones., vol. 10, no. 2, pp. 51-62, Aug. 2021, doi: 10.31000/LGRM.V10I2.4742.

[20] E. Suryanto, "Model Pendidikan Budi Pekerti Berbasis Cerita Anak Untuk Penanaman Nilai Etis-Spiritual," LITERA, vol. 12, no. 2, Jan. 2013, doi: 10.21831/LTR.V12I02.1581.

[21] Kemendikbud, Pengembangan Pendidikan Budaya dan Karakter Bangsa - Pedoman Sekolah. Jakarta: Badan Penelitian dan Pengembangan, 2010.

[22] L. J. Moleong, Metodologi Penelitian Kualitatif (Edisi Revisi). 2019.

KENDALA MAHASISWA DALAM ANALISIS MAKNA SEMANTIK PADA BAHAN AJAR BERBAHASA INGGRIS

(SALMIA SYARIFUDDIN*1, IRMAWATY HASYIM ${ }^{2}$ ) 